Journal of Southeast Asian

Volume 12

Issue 250 Years of Model Minority Stereotype

Research

2017

\title{
The Model Minority Maze: Hmong Americans Working Within and Around Racial Discourses
}

\author{
Stacey Lee \\ University of Wisconsin-Madison, stacey.lee@wisc.edu \\ Choua Xiong \\ University of Wisconsin-Madison, cxiong8@wisc.edu \\ Linda Marie Pheng \\ University of Wisconsin-Madison, pheng@siwc.edu \\ Mai Neng Vang \\ Univeristy of Wisconsind-Madison, maineng.vang@wisc.edu
}

50 Years of Model Minority Stereotype Research

Nicholas D. Hartlep

Metropolitan State University

Follow this and additional works at: https://docs.lib.purdue.edu/jsaaea

Part of the Education Commons

\section{Recommended Citation}

Lee, Stacey; Xiong, Choua; Pheng, Linda Marie; and Vang, Mai Neng (2017) "The Model Minority Maze: Hmong Americans Working Within and Around Racial Discourses," Journal of Southeast Asian American Education and Advancement: Vol. 12 : Iss. 2, Article 1.

DOI: 10.7771/2153-8999.1153

Available at: https://docs.lib.purdue.edu/jsaaea/vol12/iss2/1

This document has been made available through Purdue e-Pubs, a service of the Purdue University Libraries. Please contact epubs@purdue.edu for additional information.

This is an Open Access journal. This means that it uses a funding model that does not charge readers or their institutions for access. Readers may freely read, download, copy, distribute, print, search, or link to the full texts of articles. This journal is covered under the CC BY-NC-ND license. 


\title{
JSAAEA Journal of Southeast Asian American
Education and Advancement
}

Vol. 12 Iss. 2 Special Issue (2017)

WWW.JSAAEA.org

\section{The Model Minority Maze: Hmong Americans Working Within and Around Racial Discourses}

\author{
Stacey J. Lee \\ University of Wisconsin-Madison \\ Choua Xiong \\ University of Wisconsin-Madison \\ Linda Marie Pheng \\ University of Wisconsin-Madison \\ Mai Neng Vang \\ University of Wisconsin-Madison
}

\begin{abstract}
Whether framed as model minorities or used as evidence that the model minority is a myth, Hmong Americans and other Southeast Asians are constrained by the model minority stereotype. As a disciplinary tool, the model minority stereotype controls Asian American experiences and identities. This paper explores the complex and diverse ways that Hmong Americans in a community in Wisconsin are making sense of and responding to the model minority stereotype and the racial positioning of the Hmong American community. Our paper will illustrate the persistent power of the model minority stereotype to frame Asian American experiences, identities and actions.
\end{abstract}

Keywords: Hmong American, model minority, invisibility, social class, marginalization, racism

\section{Introduction}

Since the Civil Rights era, Asian Americans have been positioned as "model minorities" who have achieved economic and academic success through hard work, grit, and adherence to traditional

\footnotetext{
(c)

SDRERIEHISRESERVEDRReaders are free to copy, display, and distribute this article, as long as the work is attributed to the author(s) and the Journal of Southeast Asian American Education \& Advancement, it is distributed for non-commercial purposes only, and no alteration or transformation is made in the work. More details of this Creative Commons license are available at http://creativecommons.org/licenses/by-nc-nd/3.0/. All other uses must be approved by the author(s) or JSAAEA. Journal of Southeast Asian American Education \& Advancement, Vol. 12. Iss.2. Special Issue (2017) ISSN: 2153-8999
} 
cultural values. From the moment the stereotype emerged on the scene Asian American communities have been embroiled in debates over how to respond. Critical Asian American scholars have repeatedly argued that the model minority stereotype is a hegemonic tool that sustains the myth of meritocracy, silences charges of racial injustice, disciplines Black and Brown communities and masks the struggles faced by Asian American communities (Hartlep, 2013; Lee, 2009; Lee \& Kumashiro, 2005; Leonardo, 2009; Osajima, 1988; Poon et al., 2015). Fifty years after the model minority stereotype first came to national prominence it continues to be used as a tool of White supremacy to justify the racial positioning and subjugation of Asian American, African American and Latinx (Armus, 2015) students and their communities.

One strategy that scholars have used to challenge the validity of the model minority stereotype is to call for ethnically disaggregated data that uncovers the differences across various Asian American subgroups. Scholars have, for example, highlighted the high rates of poverty and academic underachievement within Southeast Asian American communities in an attempt to prove that the model minority stereotype is a myth (Lee \& Kumashiro, 2005; Walker-Moffat, 1995). A significant, but unintended, consequence of this line of scholarship is that Southeast Asian Americans have come to represent an exception to the model minority or a "failed" Asian American. As Poon and her colleagues argue, the focus on ethnically disaggregated data and the educational problems faced by some Southeast Asian American communities has contributed to the reproduction of deficit thinking and the reification of the model minority stereotype (Poon et al., 2015).

Despite years of critique from Asian American scholars, the model minority stereotype continues to frame dominant understandings of who Asian Americans are and how they are doing relative to other racial groups. Whether framed as a model minority or used as evidence that the model minority is a myth, all Asian Americans are constrained by the model minority stereotype. As a disciplinary tool, the model minority stereotype controls Asian American experiences and identities. Furthermore, the stereotype contributes to how Asian Americans respond to and understand race and racialization. This paper explores the complex and diverse ways that Hmong American youth and Hmong American community leaders in a community in Wisconsin are making sense of and responding to the model minority stereotype and the racial positioning of the Hmong American community. The article will illustrate the persistent power of the model minority stereotype to frame Asian American experiences, identities, and actions.

\section{The Hmong Experience in the United States: From Refugees to Racialized Subjects}

Hmong people, often referred to as Miao or Meo in Asia, are an ethnic group that originated from China and Southeast Asia. During the Second Indochina War (Vietnam War) and the Secret War in Laos, Hmong people in Laos were recruited as guerilla fighters to support American troops against the Communist-backed North Vietnamese Army (NVA) and Pathet Lao forces (Cha, 2010; Quincy, 2012; Vang, 2008). After the United States pulled out of Vietnam in 1975, Hmong people became targets for ethnic and political persecution (Vang, 2008). As a result of their involvement with the U.S. military, Hmong people were forced to flee from Laos to Thailand, the United States, and other European countries as refugees. After initial resettlement across the United States, many Hmong people engaged in secondary migration to California and several Midwestern states in order to maintain kinship ties and co-ethnic networks, build social and cultural capital, increase economic opportunities, and gain access to different and better educational opportunities (Chan, 
1991; Office of Refugee Resettlement, 1984; Vang, 2008). Hmong Americans have experienced economic and academic challenges since their resettlement in the United States in the mid-1970s.

Race has been a central organizing principle in the United States since the formation of the nation, and research on immigrants and refugees reveals that the process of racialization is central to becoming American (Abu El-Haj, 2015; Lee, 2005; Olsen, 1997). The dominant discourse on race centers on the White and Black dichotomy that associates Whites with desirable and positive characteristics and Blacks with undesirable and negative characteristics (Feagin, 2000). Scholarship on Asian Americans has shown that the two dominant racial discourses surrounding Asian Americans are the image of Asians as "perpetual foreigners" and the image of Asian Americans as "model minorities" (Fong, 2008; Lee, 2014; Okihiro, 1994). According to the "perpetual foreigner" stereotype, Asian Americans are continuously positioned as outsiders based on binaries of profound cultural differences: Eastern versus Western, preliterate versus modern. As noted previously, the model minority stereotype suggests that Asian Americans have achieved widespread academic and economic success through hard work and adherence to traditional Asian cultural norms. While there has been a lot of attention to the academic and economic achievements associated with the model minority image, it is important to point out that the stereotype also includes significant behavioral characteristics - hard work, self-sufficiency, obedience, respect, compliance, etc. (Petersen, 1966). Like other Asian Americans, Hmong Americans are rejected for their "foreignness" through the discourse of cultural differences, yet they are accepted as "honorary Whites" when they perform model minority achievements and behavior (Tuan, 1998). These racial discourses shape (mis) understandings of Hmong Americans in educational spaces.

The educational experiences, particularly the causes of educational inequity among Hmong Americans, are often understood to be the result of cultural clashes or cultural differences between Hmong culture and mainstream U.S. culture (Donnelly, 1994; Rumbaut \& Ima, 1988; Sherman, 1988). Within the cultural clash discourse, Hmong culture is depicted as homogenous, fixed, savage and primitive in comparison to modern Western culture (DePouw, 2012; Ngo, 2008). Hones (2002), for example, argues that due to cultural differences and limited English proficiency, parents "don't know what to expect from American schools, how to be involved, or what questions to ask regarding the schooling their children are receiving" (p. 46). Similarly, Lee and Green (2008) attribute Hmong American students' poor academic achievement to parents not being educated and not keeping track of their children's whereabouts. Xiong and Huang (2011) argue that students' low motivation level for education accounts for delinquent behaviors. As these examples demonstrate, the cultural clash discourse defaults to an individualist argument that blames parents and individuals for poor academic achievements and high truancy rates (Lee, 2015; Xiong et al., 2008). In other words, an exclusive focus on cultural differences overlooks systematic inequities (Lee, 2001).

Binary assumptions regarding Asian versus mainstream American culture and deficit perspectives on languages other than English have been identified with English as a Second Language (ESL) programs that promote English monolingualism (Xiong \& Xiong, 2011). While ESL programs do provide resources for newcomers and English learners, Xiong and Zhou's (2006) study point out that Hmong Americans are tracked into ESL based on the assumption that Hmong Americans need ESL programming simply because Hmong is spoken in the home. Importantly, research demonstrates that placement in ESL classes tracks students into lower academic classes that limit academic success (Callahan, 2005; Xiong \& Zhou, 2006).

As Asian Americans, the Hmong American community is also judged against the standards of the model minority stereotype. The scholarship on Hmong Americans and U.S. Census data on 
Hmong Americans reveal that Hmong students often struggle to achieve the levels of economic and academic achievement associated with the model minority stereotype (Ngo, 2006; Ngo \& Lee, 2007). Given the Black and White discourse of race in the United States, the academic and economic struggles experienced by Hmong Americans and other Southeast Asians lead to the ideologically blackening of these communities (DePouw, 2012; Lee, 2005; Ong, 1999).

Lee's (2005) study of Hmong Americans at University Heights School (UHS) reveals the ways that race and racism frame the educational experiences of Hmong Americans. In particular, Lee discovered that Hmong Americans at UHS who aspired to high academic achievement and reflected "traditional" Hmong values were viewed positively by their teachers. In contrast to the "traditional" students, many of the self-identified "Americanized" students questioned the value of education and adopted hip-hop styles of clothing and language associated with African American youth culture. As a result of the way the "Americanized" students performed their identities they were viewed negatively by their teachers. Most significantly, these "Americanized" students were compared to African American students or ideologically blackened within the school and thus excluded from opportunities.

Adding to Lee (2005), DePouw (2012) argues that colonialism and racism are embedded in the process of Hmong racialization based on the Black/White binary. Beyond statistical performances of the model minority and being ideologically blackened, DePouw's $(2006,2012)$ discussion of Black/White binary suggests that the process of Hmong racialization is also tied to behavioral performances. Despite Hmong Americans' academic and economic struggles, Hmong Americans are still expected to behaviorally perform a non-complaining citizenship. When Hmong American students help institutions recruit "diversity," promote cultural events, and graduate from their programs despite academic struggles, Hmong Americans successfully performed the behavioral aspects of the model minority. On the contrary, Hmong Americans are blackened when they engage in student activism, demand curriculum inclusivity in schools, and request for meaningful inclusion in campus decision-making process. In the performance of the model minority, Hmong Americans achieve honorary whiteness. When they engage in resistance, Hmong Americans become blackened. This process of racialization systematically silences and polices Hmong Americans to perform the model minority.

\section{Our Study}

The ethnographic data for this article is drawn from a larger, on-going study that examines the experiences of Hmong youth in formal and informal educational spaces in Dane County, Wisconsin. This larger project is concerned with the various messages that youth are receiving from their co-ethnic communities, families, community-based organizations and schools about their identities as Hmong youth and as students. In the tradition of in-depth ethnographic research, we are collecting data through multiple methods, including participant observation, interviews and analysis of various site documents (e.g., websites of community organizations etc.). Our participants include Hmong parents of middle and high school students, community leaders and youth workers at community centers, Hmong youth, and high school educators. We have conducted observations in community centers, college campuses, high schools and other public spaces.

This article reflects preliminary findings drawn from our interviews with parents and community leaders $(N=12)$, and from our observations of youth and community leaders in 
community centers, school board meetings, college campuses and other public spaces (to date, approximately 150 hours of ethnographic fieldwork). It is important to note that the term "community leader" is ambiguous and contested within co-ethnic communities. Our definition of community leaders includes those who advocate and/or organize on behalf of Hmong American communities, or those who other members of the Hmong community look towards as a leader. Therefore, we include members who encompass traditional leadership roles, middle-class professionals, community organizers, and college campus leaders. All interviews were recorded and transcribed, and pseudonyms are used for all participants.

Interviews and fieldwork were conducted by all members of our multi-ethnic and multilingual research team. The research team consists of the Principal Investigator, a third-generation Chinese American University professor, a second-generation Khmer American doctoral student, and two Hmong American doctoral students. Both Hmong American students were born in different refugee camps in Thailand, but came to the United States as young children and have largely been socialized and educated in the United States. Because of the ethnic makeup of the research team, we recognize that some of us are positioned as cultural insiders (Peshkin, 1991). Shared language and cultural norms are important assets in our study; yet, we also recognize that there are important regional, gender, educational attainment, and class differences that influence community norms and practices. In order to increase trustworthiness, throughout data collection and interpretation, the research team regularly engages as a group in reflecting upon findings and interpretation of data to protect against potential research bias. While we are naming Dane County, Wisconsin as the site of our research, we are using pseudonyms for all individuals and organizations to protect confidentiality and maintain anonymity of our participants. All quotes from participants are transcribed verbatim.

Finally, while we recognize that there is an ongoing debate among Hmong people in the United States regarding the terms used to describe the community (e.g., Hmong, Hmong American, or Miao/Meo), we will be using "Hmong American" to refer to our participants since this is the term most commonly used by 1.5 generation and 2nd generation Hmong people living in the United States. We recognize that there are two main sub groups within the Hmong American communities: Hmoob Dawb (White Hmong) and Moob Lees (Blue Mong) (Lee \& Tapp, 2010). While we do not want to minimize the complexity of the differences among different Hmong families and communities, for the purpose of readability, we will be using the spelling, "Hmong"; this is not intended to exclude Blue Mong.

\section{Wisconsin Context}

According to the 2010 U.S. Census Bureau, Wisconsin has the third largest Hmong population $(49,240)$ in the United States. Unlike California $(91,224)$ and Minnesota $(66,181)$, the Hmong people in Wisconsin are spread throughout the state and are not concentrated in one single area. Although Dane County does not have the largest concentration of the Hmong population in the state, Dane County does possess a significant number of Hmong people $(4,230)$ (Pfeifer et al., 2013). The Hmong American community makes up .86\% of Wisconsin's population $(49,240 / 5,686,986)$ and $1.8 \%$ of Dane County's population $(4230 / 233,209)$ (U.S. Census Bureau, 2010; Pfeifer et al., 2013). 40\% of the Hmong population works in the manufacturing industry compared to $18 \%$ of the state's population. While the Hmong American community's poverty rate has decreased over time, they remain one of the poorest ethnic groups in Wisconsin and the United States (Vang, 2013). Furthermore, Hmong American communities have one of the largest youth 
populations in comparison to the general population and the Asian American population (44\% under the age of 18) (Pfeifer et al., 2013). In addition to having one of the largest youth populations that remain in impoverished communities, Hmong Americans continue to have one of the lowest bachelor's degree attainment rates across racial and ethnic groups (Xiong, 2013).

Dane County, Wisconsin is an area known for its racialized achievement gap. The 2013 publication of the Race to Equity report revealed that for the 2012-2013 school year, 42\% of Dane County's African American high schoolers failed to graduate on time, compared to $12.7 \%$ of white students. African American students, in other words, were 3.3 times more likely to miss this key benchmark than their white peers. This $42 \%$ rate was worse than the statewide African American failure to graduate rate of $35.2 \%$. The Race to Equity report drew important attention to the educational injustices faced by the African American community in Dane County, but did not examine how other communities of color were faring in the region. Framed in this context, where Black/White disparities in education and well-being are among the worst in America, our ongoing study explores the experiences of Southeast Asian American youth in formal school spaces and out-of-school community-based spaces.

\section{Findings and Discussion}

\section{Recognition of Racial Discourses}

U.S. Census data reveal that many Hmong Americans struggle economically, with poverty rates of $37.8 \%$ (Reeves, Bennett, \& U.S. Census, 2004; Xiong, 2013). More recent data from the American Community Survey suggests that Hmong Americans are showing signs of economic improvement (Pfeifer, 2008). One of our first findings concerns the growing socioeconomic class diversity within the Dane County Hmong American community. Our participants include college educated professionals who have entered the middle-class and families and youth who live in poverty. In other words, our participants include those who appear to have achieved model minority success and those who represent the exception to the model minority or the "failed" Asian American. Interestingly, members of the middle-class Hmong American community have been active in raising awareness regarding the academic struggles faced by Hmong American students in local schools. One of the first things these college educated Hmong Americans leaders did was to push the district for disaggregated data because they believed that the aggregated data on Asian American students masked the academic concerns facing Hmong students. These leaders worked with one local Dane County School district to come up with a system to disaggregate the Hmong student data within the district. The disaggregated data from the 2013-2014 academic year reveal that the vast majority of Hmong American students in the district are identified as English learners (88\%) and are eligible for free or reduced lunch $(79 \%)$. The data also demonstrates that while Hmong American students have relatively high graduation rates, they score low on standardized tests.

In response to the disaggregated data on Hmong American students, the previously mentioned college educated Hmong American community leaders formed an educational advocacy group (Hmong Educational Advocates/HEA) to advocate for more services for Hmong American students in the district. Members of HEA argue that the data suggests that a large number of Hmong Americans are graduating from high school with limited academic skills, which will make them vulnerable for becoming trapped in low-wage jobs. While middle-class Hmong 
Americans have become increasingly focused on the educational disparities facing Hmong American students, the most economically disadvantaged members of the Hmong American community struggle to meet their basic needs and our preliminary data suggests that their voices are largely absent in the achievement gap discussions. The leader of a Hmong American organization that represents low-income Hmong American families remarked that it is difficult for families to advocate for education when they do not have access to food and housing. While an indepth discussion of Hmong American student achievement and community responses to the achievement gap are beyond the scope of our paper, we highlight the different responses to the achievement issues to demonstrate the growing social class diversity within the Hmong American community and to highlight the ways class informs responses to inequality.

Despite the growing social class diversity among the Dane County Hmong American community, our participants all demonstrate an awareness that Southeast Asians, and the Hmong American community specifically, are subjected to racial and ethnic stereotyping. Our participants are aware of both the overtly negative stereotypes facing the Hmong American community and the seemingly "positive" stereotypes of Asians more generally. Furthermore, there is a common understanding that stereotypes impact how the Hmong American community is seen and treated by the dominant society. With respect to the overtly "negative" stereotypes, our participants talked about the reliance on public assistance among Hmong American families, youth gangs, early marriage among girls, and Hmong boys dropping out of school. Not insignificantly, these stereotypes have been linked to the ideological blackening of Hmong American youth (DePouw, 2012; Lee, 2005). In terms of "positive" stereotypes, our participants' referenced characteristics associated with the model minority-hard working, quiet, good students, family-oriented, etc.

While many of our participants had not heard of the "model minority" stereotype per se, almost all were familiar with the idea that Asian Americans worked hard, were quiet and wellbehaved, did well in school, and were family-oriented. In addition to a shared awareness of the ethnic and racial stereotypes facing the Hmong American community, our participants expressed a common concern about the relative "invisibility" of Hmong and other Southeast Asian American students. Indeed, across all of our formal semi-structured interviews and in our field work, our participants expressed concerns about the lack of awareness regarding who Hmong Americans are and what concerns the community faces. Across social class backgrounds, participants regularly remarked that "people don't know who Hmong are" or "they (non-Hmong) think we are Chinese or something." The middle-class professional Hmong American participants have pointed to the exclusively Black/White discourse in the Race to Equity Report (2013) as evidence that Southeast Asian communities are largely invisible. Importantly, their awareness of racial/ethnic stereotyping and concerns regarding invisibility influence how they behave and shape their strategies for resistance.

Although all of our participants share a recognition of the relative invisibility of the Hmong American community and the simultaneous racism surrounding the Hmong American community, they did not express a common response to the racial discourses. Importantly, our preliminary findings suggest that there are heterogeneous responses to the model minority stereotype, in particular, and that the various responses are related to the social class positions and/or the social class aspirations of our participants. 


\section{Middle-Class Responses to Invisibility and the Model Minority Stereotype}

Our middle-class participants were well aware that aggregate data on Asian Americans supported the idea that Asian Americans were all high achieving students (i.e., model minorities), and that this data rendered invisible the academic concerns of Hmong American students. As noted above, middle-class Hmong American professionals worked with the school district to ethnically disaggregate student achievement. Despite their concerns about the relative invisibility of Hmong American students, however, middle-class Hmong American participants appear hesitant about expressing overt criticism of the model minority stereotype. Like the Cambodian American youth in Chhuon and Hudley's (2010) research, our middle-class participants seem to perceive the model minority stereotype to be a relatively positive representation that is preferable to the overtly negative stereotypes that the community endures.

Gao Moua, a middle-class professional who cofounded a summer program for Hmong American children and youth in Dane County, grappled with how to challenge the invisibility of Hmong American students:

Our kids are on a double-edged sword because we teach our kids to be respectful, don't challenge teachers, don't ask too many questions, right? And then when they go school they don't do that part (act out). So they seem, when they go to school or class, and not absentthey're here, so that's good enough. They're behaving, so they don't get the substance of the material that they are learning. So with that, we continue to get high graduate rates, and that puts another edge to us, but again, we are not preparing our kids for the higher education because they don't have the deep down substance for higher education.

While Gao Moua clearly recognizes that many Hmong American students have not "achieved" model minority success she emphasizes that Hmong American families value education and teach their children to act respectfully in school. In other words, she highlights the behavioral and cultural characteristics that are associated with the model minority stereotype. At the same time, however, Gao Moua recognizes that this model minority behavior contributes to the invisibility of Hmong American students, which leaves her wondering how she and the community can best advocate for Hmong American students.

Chou, a university staff who works with high school students of color, expressed a similar concern about the relative invisibility of Hmong American students in Dane County:

Peb cov Hmoob mas niam no, uh, lawv yeej face-I think lawv yeej face discrimination tsis li ntawv los lawv yeej tsis muaj enough support. For example, in this city, we have been big advocate for, niam no, more Hmong staff in the school district: teachers, uh, secretary, uh, outreach, you know, social worker, ub no. Nws tsis yog hais tias peb tsis muaj cov neeg kawm tas na, peb muaj tab sis, you know, for some reason peb ho tsis muaj ntau npaum piv xam, cov mev thiab cov dub na yod? So that's why something that lub koos haum es, uh, cov phooj ywg lawv tau tsim lub HEA no nad. Um, lawv tau tsim no ces lawv yeej advocate, li uh, (lists names of people), lawv yeej advocate for kom no, uh, thiab peb cov personal, peb yeej advocate tias kom the school district make an effort to, uh, provide service to, um, the Hmong community...First it's not a priority and secondly, budget cut, right. Uh, so yog peb cov niam txiv, the community, is not vocal about it, then it's - I mean, no news is good news, right? Lawv tsis need ces cov mev thiab cov dub lawv niaj hnub qw 
hais tias peb cov me nyuam kawm ntawv tsis tau lau, peb poob qab no ces lawv focus more on cov me nyuam dub, cov me nyuam mev.

Translation:

Us Hmong, they do face- - I think they do face discrimination and also they don't have enough support. For example, in the city, we have been big advocate for more Hmong staff in the school district: teachers, uh, secretary, uh, outreach, you know, social worker, and others. It isn't that we don't have educated people, we do, but you know, for some reason, we don't have as many as, for example, the Latinx and blacks, right? So that's why something that the organization, uh, that friends created HEA. Um, they created this organization to advocate, like, uh, (list names of people), they advocate for, uh, and us personal, we also advocate for the school district to make an effort to, uh, provide service to, um, the Hmong community... First it's not a priority and secondly, budget cut, right. Uh, so if parents, the community is not vocal about it, then it's-I mean, no news is good news, right? If they don't need then the Latinx and the blacks vocalize daily that their kids can't learn, they are falling behind, and then they will focus more on the black kids and Latinx kids.

Interestingly, Chou compares the relative invisibility of the Hmong American community with the greater visibility of the Black and Latinx communities in Dane County. While his comments suggest that he recognizes that the Hmong American, Black and Latinx communities all face barriers to education in Dane County, he does not suggest that the groups work together. Rather, he appears to view the issues facing Hmong American students to be distinct from those facing other communities of color.

During the spring of 2016 a state-wide organization for Hmong American college students in Wisconsin sponsored a conference that focused on what the model minority stereotype means for the Hmong American community, suggesting that Hmong American college student leaders recognize that the model minority stereotype is something that Hmong American communities must negotiate. At the conference, a well-respected Hmong American professor gave an historical overview of the Hmong refugee experience, and proceeded to assert that the Hmong people are an ideal minority group who have been loyal and productive citizens of the United.States. During his presentation he noted that the Hmong people were too often represented in the national discourse in overtly negative ways, and he cogently argued that these representations were not only damaging but incomplete. While recognizing that the model minority image was also an incomplete picture of the Hmong American community, the professor pointed to the many important achievements of Hmong Americans, and argued that Hmong Americans have been good and loyal citizens. Thus, the professor drew on both discourses of achievement and behavior in his discussion of Hmong Americans as model minorities. While some audience members expressed concern about the model minority stereotype, many of the students in the audience voiced support for the idea that Hmong Americans are model minorities, and several audience members noted that being stereotyped as model minorities was better than being stereotyped in overtly negative ways.

Efforts to perform a model minority identity, however, may have unintended consequences. Tong, a member of HEA, explained that in his work at a local university he had found that many Hmong American college students were hesitant to take advantage of student services and/or to 
reach out to professors because they want to present an image of themselves as self-reliant and highly successful:

What all of our students, the thing that we struggle with is where we think that asking for help is a bad thing because we think that we are too used to getting support from when we were growing up. So, we are just used to relying on the system. We are just used to relying on support, and it's a bad thing you can't help yourself. But that's how smart and wealthy kids succeed; they expect support. The minute a student of color goes and gets tutoring it's like 'oh you don't know math, you are bad at math'... I feel like you just feel it growing up, especially if you come from communities where you rely on government support or help you just think like dang we struggled and we needed people like this to help us. That when I get to college, I think I'm smart and I don't need tutors (students).... but you see all the students who go there...they don't need help, they just need to get better. This is problem for our students, among the Hmong students they definitely, they are not getting it.

In making sense of Hmong American students' hesitancy to seek academic support, it is important to recognize the hegemonic discourses around economic "dependence" versus economic "independence." In fact, when the model minority stereotype first came to prominence during the 1960's Asian Americans were valorized for their economic self-sufficiency and Blacks were simultaneously criticized for their assumed over reliance on government support (Petersen, 1966). As Tong suggests, however, Hmong American students who avoid seeking academic assistance miss out on important social capital that supports academic achievement and persistence. Thus, consistent with previous scholarship, our data suggests that efforts to conform to the model minority stereotype may lead to self-silencing and negatively impact student identity and opportunity (Lee, 2009).

\section{Low-Income Hmong Americans and the Politics of Resistance}

Like our middle-class Hmong American participants, our low-income Hmong American participants and those who work closely with these communities, are deeply concerned with the invisibility of Hmong Americans in Dane County. Mee, a youth coordinator for an advocacy group that works with Southeast Asian and Black communities in Dane County (SHOUT), expressed her frustration regarding the way the model minority stereotype masks the concerns of Hmong people:

I still think that a lot of people don't know who Hmong folks are. I think that a lot of people still think that we are East Asian, Chinese folks right? And that we fit into the model minority myth. Yeah, I think... that if they do think about Hmong people they think, I think they think about the model minority folks right. Really trying to put us into that box.

Mee goes on to assert that Hmong Americans are not model minorities:

But I think we look at those statistics right, and we take out SEA folks from that, when we look at it, we see that SEA folks are the complete opposite of the model minority myth. That we are not doing well at all. We are actually really poor, we are not graduating high school and college. All of that right. 
Interestingly, Mee suggests that Hmong American middle-class professionals may unintentionally confirm the model minority stereotype in the eyes of the dominant society through their advocacy work. In the following quote she argued that middle-class Hmong leaders are not the only leaders in the community:

Hmong leadership does not only come from young people who are professionals, right. And that it's um, that Hmong leaders comes in all shapes and forms. And that in reality at SHOUT, a lot of the Hmong leaders, a lot of folks that we think are Hmong leaders are elderly Hmong women. They are the ones that we go to, um for like, they are the one that we go to because they know whose family has not eaten, whose family does not have clothes, and whose families needs help right. And yeah, I think a lot of people look at elderly Hmong women and think that they are stupid and they don't have anything to contribute and they don't know anything. Right, and that actually, they think that they are a burden to the city and the state right. But in reality they have the most wisdom and they know the most about what the community needs.

Mee and our other low-income Hmong American participants are overtly critical of the model minority stereotype, and they also recognize that the model minority stereotype implicitly compares Asian Americans to other groups of color. Specifically, Mee argues that as Asian Americans, Hmong Americans experience relative racial privilege compared to Black people. In support of her position, she points to the disciplinary practices at schools that target Black students for behaviors that go unpunished when performed by Asian and White students.

Meng, a youth leader at SHOUT, also expressed a recognition that Whites view Hmong Americans more positively than they view Black people:

They (Whites) see us differently from black people, I think. They always say, "oh we have good food, you know. We behave well, we behave better than black folks. We have good grades or I don't know that we're healthy."

Mee and other members of SHOUT argue that efforts to perform a model minority image represent a consent to hegemonic racial discourses that damage both the Hmong American community and the Black community (Lee, 2009). In the following quote, Mee asserted that Hmong people should not strive to become model minorities:

It (the model minority stereotype) is just feeding into the system of White supremacy, not only that, but the model minority myth is very anti-Black. Everything about the model minority myth is being white, becoming White and being the furthest thing from black. We should not try to be the model minority at all. It's like we are trying to fit into the system, and the system is just using the model minority as a tool to keep us down. So that it can keep on working its magic.

Mee's critique of the model minority stereotype highlights the anti-Blackness implicit in the discourse. She recognizes that the model minority discourse is implicitly comparative in nature, and that there cannot be a model minority without a concomitant problematic minority (Lee, 2009; Poon et al., 2015). Mee and other Southeast Asian members of SHOUT have developed close 
relationships with low-income Black people through their work in SHOUT. Through their experiences working with SHOUT, Mee has seen firsthand the ways that race and class intersect with other identities in the lives of low-income communities, and she has come to recognize that low-income Black and Southeast Asians face shared forms of marginalization. Mee and other members of SHOUT argue for an intersectional approach to challenging the multiple forms of oppression faced by members of the low-income Black and Southeast Asian American communities in Dane County. Thus, Mee's critique of the model minority stereotype is based on her commitment to building cross-racial coalitions with other low-income communities of color.

\section{Conclusion}

Our research shows that Hmong people still struggle to be seen after over thirty-five years in the United States. Whether cast as model minorities or as "failed" and underachieving Asian Americans, the complex experiences of Hmong Americans are invisible. Quantitative data on Hmong American students in one school district in Dane County, Wisconsin suggests that the academic needs of Hmong American students are going largely unaddressed. Our middle-class and low-income participants are equally concerned about the invisibility of the Hmong American community and both groups recognize the role that the model minority stereotype plays in making the community invisible. In fact, their respective responses to the model minority stereotype are directly tied to their responses to invisibility. Although both our middle-class and our low-income participants are invested in advocating for the Hmong American communities, they take different approaches that reflect their respective class positions.

For middle-class participants, the dilemma appears to be about how to make visible the concerns facing Hmong American students without contributing to a deficit discourse. In other words, they want to draw attention to the academic challenges facing Hmong American students and build on assumptions regarding the good behavior of Hmong American students. As such, their response appears to be a partial challenge to the model minority stereotype. Their ambivalence regarding the model minority stereotype suggests that they recognize that being cast as model minorities is a form of relative racial privilege (Cheng, 2013). Their reluctance to directly challenge the stereotype, however, suggests that they may also recognize that despite their relative success that they are still constrained by the racial discourses controlled by the dominant group (i.e., Whites). Finally, it is important to point out that our middle-class Hmong American participants appear to be crafting a strategy for advocacy that involves framing the concerns of the Hmong American community as largely distinct and separate from concerns facing other communities of color. Here, they are implicitly drawing on a discourse that Asians are neither Black nor White (Ancheta, 2003; Okihiro, 1994; Wu, 2002).

In contrast, our low-income Hmong American participants are highly critical of the model minority stereotype. Their critique of the model minority stereotype is based on a larger critique of White supremacy and a commitment to cross-racial coalition building with Black communities. The differences between the ways our middle-class and our low-income participants make sense of and respond to the model minority stereotype point to the complex and important ways that race and class intersect in the lives of Hmong Americans in the United States. (Ng, Lee \& Pak, 2007). Regardless of social class background, however, the experiences of our participants illustrate that Hmong Americans cannot escape racialization, including racial stereotypes. Our research also demonstrates that the model minority stereotype may be a form of relative racial privilege, but it 
also contributes to the invisibility of Hmong American and other Southeast Asian students (Lee, 2005, 2009; Museus, 2009; Wing, 2007).

While most of the educational scholarship on the model minority stereotype has focused on issues of achievement, our research contributes to the scholarship that has pointed to the role of behavior in being cast as a model minority (Bascara, 2006; Osajima, 1988; Wu, 2003). Not insignificantly, "good" behavior is defined as obedience towards and compliance with the dominant norms and rules. Indeed, our research suggests that even in the absence of high academic achievement, Southeast Asian American students continue to be labeled as model minorities as long as the behavioral component is being performed. Future research should focus more attention on how Asian American students' behavior shapes ideas regarding the model minority stereotype. Finally, our research demonstrates that the model minority stereotype continues to shape Asian American experiences and identities in the 21 st century, which highlights the fact that critically conscious educational research on the impact of the stereotype remains relevant and crucial.

\section{References}

Abu El-Haj, T. T. (2015). Unsettled belonging: Educating Palestinian American youth after 9/11. Chicago: University of Chicago Press.

Ancheta, A. (2003). Race, rights, and the Asian American experience. New Brunswick, NJ: Rutgers University Press.

Armus, T. (2015). Student groups shift toward use of Latinx to include all gender identities. Columbia Daily Spectator. Retrieved from http://columbiaspectator.com/news/2015/10/07/latino-latinx

Bascara, V. (2006). Model-minority imperialism. Minneapolis: University of Minnesota Press.

Callahan, R. M. (2005). Tracking and high school English learners: Limiting opportunity to learn. American Educational Research Journal, 42(2), 305-328.

Cha, Y. P. (2010). An introduction to Hmong culture. Jefferson, NC: McFarland.

Chan, S. (1991). Asian Americans: An interpretive history. Boston: Twayne.

Cheng, W. (2013). The Changs next door to the Diazes: Remapping race in suburban California. Minneapolis: University of Minnesota Press.

Chhuon, V., \& Hudley, C. (2010). Asian American ethnic options: How Cambodian students negotiate ethnic identities in a U.S. urban school. Anthropology \& Education Quarterly, 41(4), 341-359.

DePouw, C. (2006). Negotiating race, navigating school: Situating Hmong American university student experiences (Doctoral dissertation). University of Illinois at Urbana Champaign.

DePouw, C. (2012). When culture implies deficit: Placing race at the center of Hmong American education. Race Ethnicity and Education, 15(2), 223-239.

Donnelly, N. D. (1994). Changing lives of refugee Hmong women. Seattle: University of Washington Press.

Feagin, J. R. (2000). Racist America: Roots, current realities, and future reparations. New York: Routledge.

Fong, T. P. (2008). The contemporary Asian American experience: Beyond the model minority. New York: Pearson College Division.

Hartlep, N. D. (2013). The model minority stereotype: Demystifying Asian American success. Charlotte, NC: Information Age Publishing. 
Hones, D. (2002). American dreams, global visions: Dialogic teacher research with refugee and immigrant families. New York: Routledge.

Lee, G. Y., \& Tapp, N. (2010). Culture and customs of the Hmong. Santa Barbara, CA: ABC CLIO.

Lee, J. K., \& Green, K. (2008). Hmong parental involvement and support: A comparison between families of high and low achieving high school seniors. Hmong Studies Journal, 9, 1-27.

Lee, S.J. (2001). More than "model minorities" or "delinquents": A look at Hmong American high school students. Harvard Educational Review, 71(3), 505-529.

Lee, S. J. (2005). Up against whiteness: Race, school, and immigrant youth. New York: Teachers College Press.

Lee, S. J. (2009). Unraveling the “model minority” stereotype: Listening to Asian American youth. New York: Teachers College Press.

Lee, S., \& Kumashiro, K. (2005). A report on the status of Asian Americans and Pacific Islanders in education: Beyond the model minority stereotype. Washington, DC: National Education Association Human and Civil Rights.

Lee, S. S. H. (2014). A new history of Asian America. New York: Routledge.

Lee, X. (2015). The lack of motivation to pursue postsecondary education among Hmong students: A grounded theory study (Doctoral dissertation). University of Phoenix.

Leonardo, Z. (2009). The color of supremacy: Beyond discourse of "white privilege." In E. Taylor, D. Gillborn, \& G. Ladson-Billings (Eds.), Foundations of critical race theory in education (pp. 261-276). New York: Routledge.

Museus, S. D. (2009). A critical analysis of the invisibility of Southeast Asian American students in higher education research and discourse. In L. Zhan (Ed.), Asian voices: Engaging, empowering, and enabling (pp. 59-76). New York: NLN Press.

Ng, J. C., Lee S. S., \& Pak, Y. K. (2007). Contesting the model minority and perpetual foreigner stereotypes: A critical review of literature on Asian Americans in education: Review of Research in Education, 31(1), 95-130.

Ngo, B. (2006). Learning from the margins: The education of Southeast and South Asian Americans in context. Race Ethnicity and Education, 9(1), 51-65.

Ngo, B. (2008). Beyond "culture clash" understandings of immigrant experiences. Theory into Practice, 47(1), 4-11.

Ngo, B., \& Lee, S. J. (2007). Complicating the image of model minority success: A review of Southeast Asian American education. Review of Educational Research, 77(4), 415-453.

Office of Refugee Resettlement. (1984). The Hmong resettlement study: Executive summary. Washington, D.C: U.S. Government Printing Office.

Okihiro, G. Y. (1994). Margins and mainstreams: Asians in American history and culture. Seattle: University of Washington Press.

Olsen, L. (1997). Made in America: Immigrant students in our public schools. New York: The New Press.

Omi, M., \& Winant, H. (2014). Racial formation in the United States. New York: Routledge.

Ong, A. (1996). Cultural citizenship as subject making: Immigrants negotiate racial and cultural boundaries in the United States. Current Anthropology, 37(5), 737-762.

Osajima, K. (1988). Asian Americans as the model minority: An analysis of the popular press images of the 1960s and 1980s. In G. Y. Okihiro, S. Hune, A.A. Hansen, \& J. M. Liu (Eds.), Reflections on shattered windows (pp. 165-174). Pullman, WA: Washington State University Press. 
Peshkin, A. (1991). In search of subjectivity—one's own. In C. F. Conrad, J. G. Haworth, \& L. R. Lattuca (Eds.), Qualitative research in higher education: Expanding perspectives (pp. 455-461). Boston: Pearson Custom.

Petersen, W. (1966). "Success Story, Japanese-American Style." The New York Times Magazine, $6,20-43$.

Pfeifer, M. (2008). "Cambodian, Hmong, Lao and Vietnamese Americans in the 2005 American Community Survey." Journal of Southeast Asian American Education and Advancement, 3, 1-21.

Pfeifer, M. E., Sullivan, J., Yang, K., \& Yang, W. (2013). Hmong population and demographic trends in the 2010 Census and 2010 American Community Survey. In M.E. Pfeifer \& B.K. Thao (Eds.), State of the Hmong American community (pp. 8-9). Washington, DC: Hmong National Development.

Poon, O. A., Squire, D., Kodama, C., Byrd, A., Chan, J., Manzano, L., Furr, S., \& Bishundat, D. (2015). A critical review of the model minority myth in selected literature on Asian Americans and Pacific Islanders in higher education. Review of Educational Research, 86(2), 469-502.

Quincy, K. (2012). From war to resettlement: How Hmong have become Americans. In V. Her, \& M. L. Buley-Meissner (Eds.), Hmong and American: From refugees to citizens (pp. 5980). St. Paul, MN: Minnesota Historical Society Press.

Race to Equity Project Team. (2013). Race to equity: Baseline report on the state of racial disparities in Dane County. Madison, WI: Wisconsin Council on Children and Families.

Reeves, T., Bennett, C. E., \& U.S. Census Bureau. (2004). We the people: Asians in the United States. Washington, DC: U.S. Dept. of Commerce, Economic and Statistics Administration, U.S. Census Bureau.

Rumbaut, R. G., \& Ima, K. (1988). The adaptation of Southeast Asian refugee youth: A comparative study. Washington, DC: U.S. Office of Refugee Resettlement.

Sherman, S. (1988). "The Hmong in America: Laotian refugees in the "land of the giants." National Geographic, 174, 586-610.

Tuan, M. (1998). Forever foreigners or honorary Whites?: The Asian ethnic experience today. New Brunswick, NJ: Rutgers University Press.

U.S. Census Bureau. (2010). 2010 U.S. Census interactive population search - Wisconsin Washington, DC: Government Printing Office. U.S. Census Bureau. Retrieved from http://www.census.gov/2010census/popmap/ipmtext.php?fl=55.

Vang, C. Y. (2008). Hmong in Minnesota. Minneapolis, MN: Minnesota Historical Society.

Vang, C. Y. (2013). Hmong socioeconomic trends in the U.S. In M. E. Pfeifer \& B. K. Thao (Eds.), State of the Hmong American community (pp. 21-28). Washington, DC: Hmong National Development.

Walker-Moffat, W. (1995). The other side of the Asian American success story. San Francisco: Jossey-Bass.

Wing, J. Y. (2007). Beyond black and white: The model minority myth and the invisibility of Asian American students. The Urban Review, 39(4), 455-487.

Wu, F. H. (2002). Yellow: Race in America beyond black and white. New York: Basic Books.

Xiong, Y. S., \& Zhou, M. (2006). Six: Structuring inequality: How California selectively tests, classifies, and tracks language minority students. UCLA School of Public Affairs. Retrieved from: http://escholarship.org/uc/item/98d66346 
Xiong, Y. S. (2013). Recent changes and remaining challenges in Hmong Americans' educational attainment. In M.E. Pfeifer \& B.K. Thao (Eds.), State of the Hmong American community. Washington, DC: Hmong National Development.

Xiong, Y. S., \& Xiong, N. (2011). The prevalence of English monolingualism and its association with generational status among Hmong Americans, 2005-2009. Hmong Studies Journal, 12(1), 1-22.

Xiong, Y. S. (2013). An analysis of poverty in Hmong American communities. In M. Pfeifer, M. Chiu, \& K. Yang (Eds.), Diversity in diaspora: Hmong Americans in the twenty-first century (pp. 66-105). Honolulu: University of Hawaii Press.

Xiong, Z. B., Tuicomepee, A., \& Rettig, K. D. (2008). Adolescents' problem behaviors and parentadolescent conflicts in Hmong immigrant families. Hmong Studies Journal, 9, 1-21.

Xiong, Z. B, \& Huang, J. (2011). Predicting Hmong male and female youth's delinquent behavior: An exploratory study. Hmong Studies Journal, 12, 1-34. 


\section{About the Authors}

Stacey J. Lee is a professor in the Department of Educational Policy Studies and faculty affiliate in Asian American Studies at the University of WisconsinMadison. She is the author of Unraveling the Model Minority Stereotype: Listening to Asian American Youth and Up Against Whiteness: Race. School \& Immigrant Youth.

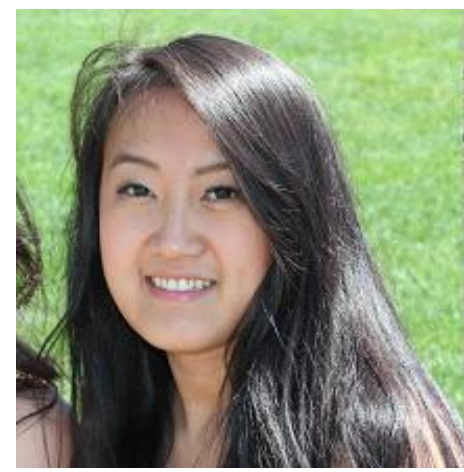

Choua Xiong is a graduate student in the Educational Policy Studies department at the University of WisconsinMadison. She is broadly interested in how educational spaces shape Hmong youth's sense of belonging and citizenship. She hopes to further explore the educational experiences of Hmong in Southeast Asia for her dissertation research.

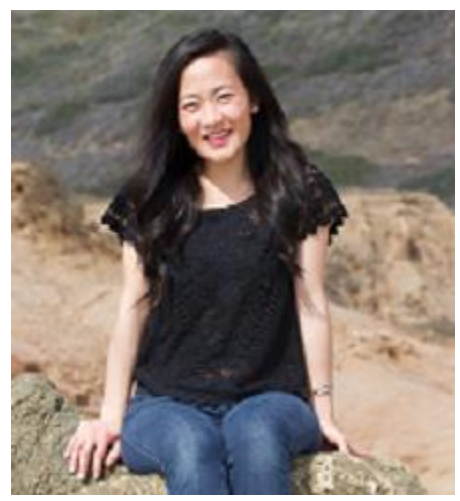

Mai Neng Vang is a graduate student in the Educational Policy Studies program at the University of WisconsinMadison. She has a broad research interest in the educational experiences of immigrant and refugee students. More specifically, she is interested in understanding how race, ethnicity, gender, and class intersect to inform the lives and experiences of Hmong American students and their families.

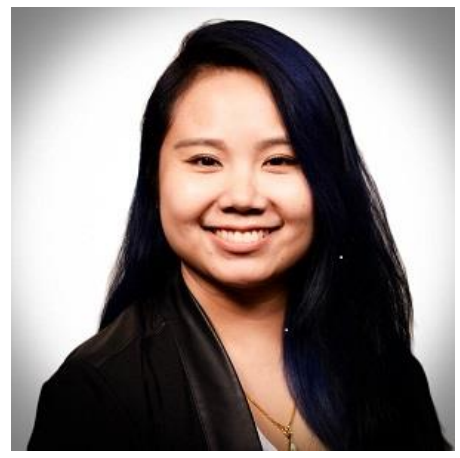

Linda Marie Pheng is a doctoral student in the Department of Educational Policy Studies at the University of Wisconsin-Madison. Her research examines the ways race, class, gender, and immigration intersect in the educational experience of Southeast Asian American youth and communities in urban settings. 


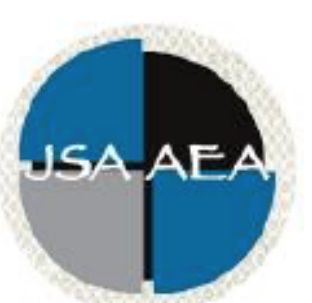

Vol.12 Iss.2 Special Issue (2017)

\section{Journal of Southeast Asian American}

\section{Education and Advancement}

\author{
Special Issue Editor \\ Dr. Nicholas D. Hartlep \\ Metropolitan State University
}

Editor

Dr. Wayne E. Wright

Purdue University

Associate Editors

Dr. Chhany Sak-Humphry

University of Hawaii at Manoa

Dr. Phitsamay Sychitkokhong Uy

University of Massachusetts, Lowell

\title{
Book Review Editor \\ Dr. Vichet Chhuon
}

University of Minnesota

Creative Works Editor

Bryan Thao Worra

Lao Assistance Center

\section{Journal Manager}

Sung Ae Kim

Purdue University

\section{Editorial Review Board}

Dr. Steve Arounsack

California State University, Stanislaus

Dr. Sovicheth Boun

The State University of New York, Fredonia

Dr. George Chigas
Dr. Carl L. Bankston III

Tulane University

Dr. Angela Reyes

Hunter College, The City University of New York

Dr. Loan Dao 
University of Massachusetts, Lowell

Dr. Hien Duc Do

San Jose State University

Dr. Sophal Ear

Occidental College

Dr. Virak Chan

University of Texas at San Antonio

Dr. Jeremy Hein

University of Wisconsin, Eau Claire

Dr. Nancy H. Hornberger

University of Pennsylvania

Dr. Peter Nien-Chu Kiang

University of Massachusetts, Boston

Dr. Ha Lam

Eastern Mennonite University

Dr. Jonathan H. X. Lee

San Francisco State University

Dr. Monirith Ly

Royal University of Phnom Penh

Dr. Bic Ngo

University of Minnesota

Dr. Leakhena Nou

California State University, Long Beach

Dr. Mark Pfeifer

SUNY Institute of Technology

Dr. Loan T. Phan

University of New Hampshire

Dr. Kalyani Rai

University of Wisconsin, Milwaukee

Dr. Cathy J. Schlund-Vials

University of Connecticut, Storrs

Dr. Nancy J. Smith-Hefner

Boston University

Dr. Yer J. Thao

Portland State University

Dr. Monica M. Trieu

Purdue University

Dr. Silvy Un

Saint Paul Public Schools

Dr. Terrence G. Wiley

Center for Applied Linguistics
University of Massachusetts, Boston

Dr. Changming Duan

University of Missouri, Kansas City

Dr. Sothy Eng

Lehigh University

Dr. Zha Blong Xiong

University of Minnesota

Dr. Vincent K. Her

University of Wisconsin, Eau Claire

Dr. Peter Tan Keo

New York University

Dr. Kevin K. Kumashiro

University of San Francisco

Dr. Ravy Lao

California State University, Los Angeles

Dr. Stacey Lee

University of Wisconsin, Madison

Dr. Sue Needham

California State University, Dominguez Hills

Dr. Max Niedzwiecki

Daylight Consulting Group

Dr. Clara Park

California State University, Northridge

Dr. Giang Pham

University of Massachusetts

Dr. Karen Quintiliani

California State University, Long Beach

Dr. Phala Chea

Lowell Public Schools

Dr. Fay Shin

California State University, Long Beach

Dr. Christine Su

Ohio University

Dr. Alisia Tran

Arizona State University

Dr. Khatharya Um

University of California, Berkeley

Dr. Linda Trinh Vo

University of California, Irvine

Dr. Yang Sao Xiong

University of Wisconsin-Madison 


\section{Doctoral Student Editorial Review Board}

\author{
Anna H. Yang \\ University of Georgia \\ Annie BichLoan Duong \\ San Joaquin County Office of Education \\ Hoa Nha Nguyen \\ Boston College \\ Malaphone Phommasa \\ Marshall University \\ Molly Wiebie \\ The University of Texas at Austin
}

\author{
Dung Minh Mao \\ University of Minnesota \\ Thien-Huong Ninh \\ University of Southern California \\ Krissyvan Truong \\ Claremont Graduate University \\ Soua Xiong \\ San Diego State University \& Claremont \\ Graduate University
}

